\title{
О мифологических мотивах в былине “Добрыня и Настасья"
}

\section{= Максим А. Ююкин \\ This article deals with mythological motifs reflected in the bylina "Dobrynya and Na- stas'ya" discussed in comparison with the Baltic, South Slavic, and Ossetic epic texts. KEYWORDS: Slavic mythology, bylina, "Dobrynya and Nastasya", principal myth, mythological images, parallels}

\section{ВВЕДЕНИЕ}

Факт отражения в былинах мифологических представлений восточных славян хорошо известен. При этом, как отмечает, например, Б. Н. Путилов (1999: 18), количество былин, сохранивших мифологические сюжеты в “чистом" виде, невелико (к ним он относит всего три: “Исцеление Ильи Муромца”, “Богатырь и чудесная сумочка”, “Илья Муромец и Святогор”). Чаще мифологические мотивы присутствуют в былинах в виде отдельных реминисценций; наиболее заметны они в таких произведениях, как “Михайло Потык”, “Дунай”, “Волх Всеславьевич” и др.

Былина “Добрыня и Настасья” (“Женитьба Добрыни”) (которая в некоторых записях контаминирована с другими былинами о Добрыне Никитиче - “Добрыня и змей”, “Добрыня и Алеша”; перечень опубликованных вариантов см. в Добрыня... 1974: 395) не входит ни в первый, ни во второй список. Между тем ее сюжет, на наш взгляд, восходит к последнему эпизоду основного индоевропейского мифа и обнаруживает параллели в балтских и южнославянских эпических текстах.

Фабула былины следующая. Добрыня (в контаминированных вариантах возвращающийся после победы над змеем), повстречав в чистом поле богатыря в женской одежде, нападает на него, но тот не обращает на Добрыню никакого внимания. Озадаченный герой, засомневавшись в своей силе, испытывает ее, разбивая в щепки дуб толщиной в человеческий обхват. Воспрянув духом, Добрыня снова совершает нападение, и ситуация повторяется (только теперь расщепляется уже дуб в два обхвата). Лишь после третьего удара Добрыни богатырка оборачивается, берет нападавшего за кудри и кладет вместе с конем в мешок. Однако ее 
конь отказывается везти одновременно двух могучих богатырей. Тогда Настасья Микулична достает Добрыню из мешка (в некоторых вариантах обращаясь к нему по имени, чем вызывает у него удивление). Она говорит, что если он человек зрелого возраста, то будет ей вместо отца, если молодой человек и полюбится ей, - станет ее любимым другом, а если придется ей не по нраву, - “на долонь кладу, другой прижму и в овсяный блин ёго да сделаю” (Гильфердинг 1873: 38). Вынужденный под угрозой смерти согласиться на брак с могучей девой, Добрыня привозит ее в Киев, представляет матери и князю Владимиру, после чего происходит их венчание. Различные записи не обнаруживают значительных сюжетных расхождений. В единичных вариантах силы богатырей оказываются равными и инициатива женитьбы исходит от Добрыни (Григорьев 1904: I 196-197; Былины Пудожского края 1941: 34); в одном случае победа остается за Добрыней (Крюкова 1939: 267-268).

\section{СЮЖЕТ ОСНОВНОГО МИФА В БЫЛИНЕ “ДОБРЫНЯ И НАСТАСЬЯ” И ПАРАЛЛЕЛИ К НЕМУ}

Как указывают Вяч. Вс. Иванов и В. Н. Топоров (1974: 96), “последний эпизод мифа делится на две основные части: 1) победа Бога Грома над противником, реализующаяся в расщеплении или сожжении дерева (дуба) или в расщеплении камня, под которыми скрывается его противник, 2) высвобождение вод (дождя) или скота, плодородия, богатства, которое скрывалось у противника бога”. Согласно Дж. Дж. Фрэзеру (1986: 156), культ дуба (или бога дуба) существовал, по-видимому, у всех индоевропейских народов арийского происхождения. А. Н. Афанасьев ([1865-1869]: I [26 и др.]) с наивной прямолинейностью в духе мифологического метода интерпретировал дуб как метафору дождевой тучи. За пределами устного народного творчества отдельные реминисценции основного мифа на славянской почве обнаруживаются в основном также у южных славян: ср., например, обычай изгнания змея (гоненето на змий) в болгарских ритуалах вызывания дождя (Толстые 1978: 114). Ассоциация дуба и дождя известна и у финно-угров: эрзя при молитве о дожде обращалась к дубу и говорила: “бог дуба (Тумо-пас), дай дождь” (Holmberg 1927: 252).

Ключевой эпизод первой части - расщепление дерева (дуба) - дважды повторяется в былине (“АА стоит же во чистом поли да сырой дуб Да в обнём же он стоит да человеческий. Наезжает же Добрынюшка на сырой дуб А попробывать да силы богатырскии. Как ударит тут Добрынюшка во сырой дуб, Он росшиб же дуб да весь по ластиньям... Он стоит-то в два обнёма человеческих...” (Гильфердинг 1873: 37), что в сочетании с мотивом женитьбы/поединка героя с противницей женского пола (тождество этих двух его вариантов понятно с учетом распространенной фольклорной метафоры “женитьба - битва”(о последней см. Новичкова 1987: 11) роднит ее с латышскими дайнами и болгарской песней “Крали Марко и Вида самовила”. Вот одна из дайн в русском переводе: 
Месяц женился на Солнцевой дочери,

Перкуанс поехал в сваты.

Въезжая в ворота,

Он разбивает золотой дуб.

Обрызгивает мой коричневый кафтан

Кровью дуба.

Последняя подробность в сравнении с тождественным описанием в другой песне показывает изофункциональность дуба противнику бога (на основании метонимического переноса, так как согласно основному мифу, последний прячется в дупле дуба (см. Иванов, Топоров 1974: 6):

Я рассек голову беса

На девять частей.

У меня обрызгался коричневый кафтан

Кровью бесовской.

Иногда разбивание дуба происходит дважды, как и в рассматриваемой былине:

Месяц женился на Солнцевой дочери.

Перкуанс ехал в догонщиках.

На пути туда и обратно

Он разбивает золотой дуб

(Сборник... 1873: 25-27).

П. Шмидт по поводу этого сюжета обращает внимание на то, что “это может быть очень старый миф” (Šmits 1926: 24-25).

Ассоциацию между сюжетом былины и балто-славянскими представлениями о супружеских отношениях солнца и месяца (мотивы балтского мифа о небесной свадьбе также присутствуют в процитированных текстах) вызывает типичное для причитаний сравнение (в причитании матери Добрыни) Добрыни с солнцем, а Настасьи с месяцем: “Закатилося сугревное меженное теплое красное солнышко За лесушки да темные, за горушки да высокие, За мхи, за озера за широкие. Столько светит на меня теперичку светел месяц, - Осталася со мной невестушка молода Настасья дочь Микулична” (Гильфердинг 1873: 580-581).

Более развернутый, чем в дайнах, сюжет представлен в болгарской песне, в которой герою, как и былинному Добрыне, приходится иметь дело с противницей женского пола:

тук е фтесна Вида самовила;

заключила дванайсе извори

стред гората в едно суво дърво, по сфе суво, на въро зелено!.. 
го намери това суво дърво;

по сфе суво, на въро зелено.

Та го фати с тешка боздугана,

го изтроши комат по комата;

и му строши дванайсе ключови,

та притекоа дванайсе извори

(БНТ 1961: IV 158; русский перевод см. в Песни южных славян 1976: 45).

В отличие от былины, результат встречи южнославянского богатыря с могучей противницей является трагическим: Марко убивает самовилу, что отражает исконный вариант мифа: В. Н. Топоров (1986: 56-58) сравнивает песню о Марко и Виде-самовиле с мифами о Вритре и Вале, из чего вытекает понимание образа вилы как трансформации первоначального змея - противника бога грома (к этим выводам, однако, пришел еще М. Г. Халанский (1893: 337, 345). Мифологическая же основа образа королевича Марко связывается с культовым образом фракийского всадника и духом-защитником предков (Е. Тодоров) (см. Путилов 1999: 19-20).

В сербской песне мы встречаем другой вариант этого сюжета: Марко бьет палицей по ели, чтобы стряхнуть наземь сидящую на ней вилу, и хватает свою жертву за ее 12 кос (Халанский 1893: 312), явно идентичных 12 источникам болгарской баллады.

Помимо рассматриваемой былины, в русском фольклоре мы находим лишь слабые, отрывочные следы эпизода расщепления дуба, в которых первоначальный контекст полностью редуцирован: так, сказочный герой бьет по дубу, чтобы вызвать летучий корабль; в другой сказке это дерево расщепляет орел (Афанасьев [1865-1869]: I [158, 177]). В большей степени исконное мифологическое содержание этого эпизода сохранилось в сцене расстрела старого дуба, в котором прячется царь Змиулан (сказка “Козьма Скоробогатый”) (Сказки 1989: 2 136). Чаще же вместо дуба своеобразному расщеплению подвергается сам образ дерева, внутри которого заключены воды: герой добывает у девы-богатырки молодильные яблоки с чудесного дерева и живую и мертвую воду (Народные... 1984-1985: I 349-374; Великорусские... 1964: 53-59), однако непосредственная связь между деревом и водой здесь отсутствует. Следует упомянуть и уникальный, несомненно архаичный вариант, в котором присутствуют все три участника первоначального мифического действия (герой(-громовержец), змей и дуб): “...я иду по дороге, кричит мне дуб: “Скажи царю-та, долго ли мне еще стоять?”. - “Ему стоять до тех пор, - сказал царь, - как подойдет к нему кто да толкнет его ногою, тогда он выворотится с корнем и упадет, а под ним злата и серебра многое множество - столько нет у Марка Богатого!”... Сказал царь Змий и заснул крепким сном” (Народные... 1984-1985: II 349). Полнее заключительный эпизод мифа сохранился в белорусских сказках, где Перун (или царь Гром) разбивает дуб, часто в ходе поединка с чертом (Иванов, Топоров 1974: 97).

Мотив заключенных в дубе вод и их последующего высвобождения, в неприкосновенности сохраненный болгарским фольклором, подвергся метафорическому переосмыслению у балтов, в дайнах которых вода превратилась в кровь дуба. Отзвук 
исконного образа ощущается, однако, в упоминании реки, из которой вытекают девять ручейков (или озера, из которого вытекают девять рек), где следует постирать испачканный кровью кафтан. В былине же этот мотив оказался полностью утраченным, вследствие чего акт расщепления дуба получил явно вторичную мотивацию испытания героем своей силы. Однако было бы неверно утверждать, что мотив сокрытых в дубе вод вообще не встречается на восточнославянской почве; в записанной на периферии старой русской территории (в бывшей Самарской губернии) сказке мы находим поистине драгоценное (по-видимому, единственное) свидетельство того, что не сохранила былина: “Во дворе же был царском превеличащий каракульский [т. е. суковатый, см. (СРНГ 1965-: 13 71)] дуб; в этом дубу сохранялася живая и мертвая вода. Она сохранялася, никому не открывалася" (Сказки 1988: 1 419). Далее супруга убитого царевича тщетно просит эту воду у дуба; лишь совместная мольба трех сестер приводит к успеху; таким образом, способ добычи воды здесь уже ритуализирован и в корне отличается от брутального насилия героя мифа. Эхо мотива открытия вод вопреки воле охраняющего их змея доносят гневные слова девы Синеглазки: “Мне не то жалко, что коня напоил, а то дорого, что колодцика не прикрыл!” (Сказки Белозерского края 1981: 270). Как видно из приведенных фактов, былина “Добрыня и Настасья" является наиболее полным, единственным связным (хотя и в значительной степени деградированным) изложением последнего эпизода основного мифа в русских источниках.

Во всех вариантах слово дуб сопровождается постоянным фольклорным эпитетом cырой. Т. В. Топорова (2011: 59-60) попыталась объяснить формулу сырой дуб как мужское соответствие другому традиционному выражению народной поэзии - мать cыра земля, причем это противопоставление, по мнению автора, манифестирует универсальную космогоническую оппозицию “небо - земля”. Однако сравнительный материал свидетельствует, что употребление этого эпитета по отношению к дубу и, следовательно, сближение дуба и земли в рамках устойчивых выражений с его использованием носит вторичный характер. Оно является результатом энантиосемии (вероятно, облегченной влиянием со стороны упомянутой формулы мать сыра земля): в соответствующих балтских и болгарских текстах дуб (дерево) называется сухим (“'заключила дванайсе извори стред гората в едно суво дърво”; “Sper, Pērkoni, sausu koku, K̦īlè zal̦u ozolin̦u”, №33716-0 (Dainu skapis), что согласуется как с природными свойствами этого дерева, так и с его мифологической связью с понятием засухи (закрытых вод). Никакой корреляции дуба и земли в этих примерах также не наюлюдается. Обращает на себя внимание и тождественность описания дуба в латышской и болгарской песнях (сухой, но зеленый (с зеленой вершиной), указывающая на его происхождение из более раннего общего архетипа, в отличие от совершенно иной характеристики дуба в былинах. Искусственность построения Т. В. Топоровой очевидна и с учетом глубинной семантики образа дуба: образ мирового древа (а с тем, что дерево (дуб) основного мифа является репрезентацией последнего, согласны все исследователи) воплощает трехчастную модель мира (см. Топоров 1994: 399 и сл.), а вовсе не соотносится с одним лишь верхним его ярусом. 


\section{ГЛАВНЫЕ ГЕРОИ БЫЛИНЫ И ИХ ПРОИСХОЖДЕНИЕ}

\section{НАСТАСЬЯ МикУЛИчНА}

Для понимания мифологической основы былины “Добрыня и Настасья” очень важны также образы двух главных героев, в которых, наряду с уже отмечавшимися в литературе, можно выделить ряд черт, до сих пор ускользавших от внимания исследователей. Остановимся на них подробно.

В. Вольнер первым обратил внимание на сходство описаний, касающихся Настасьи Микуличны и Святогора (Wollner 1879: 66); это наблюдение многократно повторяется в более поздних работах. Однако О. Ф. Миллер (1869: 438) еще раньше сопоставил Настасью с образом, который следует признать необходимым промежуточным звеном, связующим этих двух персонажей. Речь идет о былине "Илья Муромец и Святогор" (Марков 1901: 307-310; Коргуев 1939: 221-222; Былины Печоры 1961: 212), где важную роль в развитии фабулы играет не названная по имени жена Святогора, также наделенная богатырской силой, которую она получила с остатками питья своего мужа. Таким образом, метонимический перенос на этот образ богатырских свойств Святогора нашел отражение даже на сюжетном уровне. С этой фигурой действительно связан целый ряд мотивов, тождественных тем, которыми характеризуются отношения Настасьи и Добрыни. Помимо упомянутых О. Ф. Миллером (жена Святогора кладет Илью (так же, как и Настасья Добрыню) в мешок или прямо в карман к Святогору; конь отказывается везти одновременно двух богатырей), это и возникающие между ней и Добрыней любовные отношения (за что Святогор в некоторых вариантах позднее убивает жену), и пространственное расположение героев относительно друг друга (в печорском варианте жена Святогора видит сидящего на дубу Илью в зеркале, т. е. Илья находится позади нее, как и Добрыня по отношению к Настасье во время нападения на нее: “А назад тут поляница не оглянется” (Гильфердинг 1873: 37). Архаичность этого сюжета сомнений не вызывает: как указывалось выше, Б. Н. Путилов относит былину “Илья Муромец и Святогор” к числу всего трех, в которых мифологические сюжеты сохранились в “чистом” виде.

В беломорском варианте этой былины Святогор возит жену в хрустальном ящике, который открывает золотым ключом (Марков 1901: 307-310). Едва ли можно сомневаться в близких генетических связях этого ящика с известным из сказок прозрачным (стеклянным, иногда золотым или серебряным, в русских сказках обычно также хрустальным) гробом, в который кладут мертвую принцессу. В классификации Аарне-Томпсона этот сюжет учтен под №709; в западноевропейской традиции он известен под названием “Белоснежка"; у восточных славян - как “Волшебное зеркальце” или “Мертвая царевна” (Aarne 1910: 24; Андреев 1929: 50; Thompson 1961: 245; Сравнительный... 1979: 179). Следует также упомянуть хрустальную гору из одноименной русской сказки, из которой герой освобождает заключенную в нее царевну. Эта подробность указывает на связь образа жены Святогора с загробным миром. 
В указанном тексте этот ящик именуется словом раец: “На плечах-то он ведь держит хрустальный-от раец-от” (Марков 1901: 307), известным только по этой записи; его значение считается неясным (см. СРНГ 1965-: 33 251). По нашему мнению, это слово является диахроническим словообразовательным дублетом (типа городьц̧ь : городъкъ) слова раёк 'ящик с передвижными картинами, на которые смотрят через толстое стекло (Даль 1994: III 1468); вид кукольного театра; галерка', которое представляет собой деминутив от рай (см. Фасмер 1996: III 432). Правильность этого объяснения подтверждается вариантом, записанным на Печоре, в котором фигурирует слово ящик (Былины Печоры 1961: 212).

Образ Настасьи Микуличны (Микулишны) нельзя рассматривать изолированно от близких образов других дев-богатырок в русских сказках и былинах (Марья Моревна, Усоньша-богатырка, Синеглазка, (3)латыгорка, безымянная дочь Ильи Муромца, Белая Лебедь Захарьевна), в южнославянском эпосе о королевиче Марко (вилы, Арватка (или Джидовка) (о последней см. Путилов 1971: 88-90; более отдаленные связи, вроде часто упоминаемых в связи с этим амазонок, мы не рассматриваем). Некоторые из них позволяют проследить мотивы основного мифа, не сохранившиеся в дошедших до нас былинах о Настасье.

Так, о змеиных истоках образа Виды-самовилы напоминает использование ей змей в качестве узды и плетки для оленя (“Го зачула Вида самовила, та фатила един сури елен, ем фатила до три люти змии; двете, змии удзи му ги кладе, а едната камшик я направи" (БНТ 1961: IV 158). Вилы (самовилы, самодивы) в сербском фольклоре также возводятся к хтоническому образу змея (как его женское соответствие), ср. особенно следующие стихи из песни, записанной в восточной Сербии: “Самодиви, самовили, И ви 'е лоши “уди, И ви 'е бели русалин, Сиви шарени зме’ове!” (Петровић 1999: 71-72).

Имя Усоньши-богатырши соотносимо с именем сказочного богатыря Усыни (вероятно, здесь произошло сближение с сон, уснуть (ср. русск. диал. сонша (твер.), соньша (новг., пск.) 'тот, кто много спит' (Даль 1994: IV 387), поскольку по сюжету сказки герой застает Усоньшу спящей), в образе которого сохранились отчетливые змеиные черты: в одной сказке он выступает как птица Усыня - змей о 12 головах (Великорусские... 1964: 60), ср.: "Усыня сопоставим с образом дракона или змея, запруживающего воды своими плечами” (Иванов, Топоров 1990: 159). При этом в образе Усыни ощутим отзвук отождествления противника героя (громовержца) с дубом, аналогичное тому, которое мы видели выше в латышских дайнах: “Он [Усыня], как дуб, упал на землю, умер” (Великорусские... 1964: 60). Показательно, что обе эти сказки (об Усоньше-богатырше и об Усыне) записаны в одном населенном пункте - селе Мишино бывшей Рязанской губернии.

Вместе с тем в образе Усыни присутствуют и солярные мотивы, а именно близкая ассоциация с солнечным годом, на что указывают 365 птичьих гнезд, находящихся на усе сербского соответствия Усыне Брко (с.-хорв. брк 'ус') (наблюдение о тождестве этих образов см. в Афанасьев [1865-1869]: II 264): “човјек му рекне: “Море и Брко је неки: саде ћеш га виђети”. У том стане ука с једне стране, док се иза брда помоли један брк и у њему триста и шездесет и пет тичији гнијезда. Мало-помало 
помоли се и други брк; ете и Брка” (Караџић 1870: 4; русский перевод см. в Сказки народов Югославии 1962: 151). В (Кулишић et al. 1970: 52) лишь излагается содержание этой сказки, какая-либо интерпретация образа Брко там отсутствует. На связь Усыни русской сказки с солнцем, возможно, намекает тот факт, что герой встречается с ним в золотом царстве.

Местонахождение змея в основном мифе - у корней мирового древа (см. Топоров 1994: 400). В этом контексте чрезвычайно выразительна такая деталь, как деревья, растущие под мышками у Усоньши-богатырши: “В третью комнату входит, там спит сама Усоньша-богатырка. И у ней, когда она почивает, из косточки в косточку мозжечок переливается, под мышками дерева с яблоками цветут” (Великорусские... 1964: 56) (Усыня также связан с яблоней, к которой он прилетает и подрывает ее корни (там же: 59).

В этой связи следует упомянуть и связь девы Златыгорки (былина “Илья Муромец и Сокольник”) с камнем Алатырь (образ, изофункциональный мировому древу). В редком и при этом густо насыщенном архаическими мотивами варианте “Добрыни и Настасьи”, где вместо Добрыни Никитича выступает Дунай Иванович, Настасья также локализуется близ Алатыря (названного “кружалом богатырским”, т. е. местом встречи богатырей) и даже на нем самом: герой видит ее спускающейся с его южной стороны (Крюкова 1939: 443).

Образ не названной по имени дочери Ильи Муромца соотносится с образом мирового древа даже более тесно, потому что эта связь выражается в ее внешнем облике. На правой руке у нее сидит соловей, а на левой - жаворонок (Илья Муромец 1958: 209), ср. связь в восточнославянской традиции птиц с вырием (обозначение рая и мирового древа, на котором сидят птицы (см. Иванов, Топоров 1994 а: 254; Иванов, Топоров 1994 в: 348). Внешность этой героини имеет больше общего с деревом, покрытым листвой, чем с человеческим существом: “У ней шапочка надета на головушку А й пушистая сама завесиста, Спереду-то не видать личка румяного И сзаду не видеть шеи белоей” (Илья Муромец 1958: 207-208).

Эта безличность - очевидный рудимент более ранней, доантропоморфической стадии развития образа. Мотив отсутствия лица (выступающий в варианте, соответствующем следующей стадии антропоморфизации) присутствует и в образе Настасьи (в упомянутом выше варианте с Дунаем): “Поляниця-то ездит в маски, Надета на лицё, подведена, Будто старым-то она старая, Будто древняя она старуха-то" (Крюкова 1939: 445). В финале Илья Муромец разрубает тело дочери на куски; эта прямая аналогия с эпизодом расщепления дуба заставляет вспомнить изофункциональность противника громовержца и дуба, которую мы наблюдали выше. Эквивалентность символов мирового древа и женщины (переодетой деревом) подтверждается различными индоевропейскими и другими традициями, особенно балканскими ритуалами (см. Иванов, Топоров 1974: 36).

На отношение образа девы-воительницы к нижнему миру, миру смерти (о чем уже упоминалось выше) указывает и имя Марья Моревна в русской сказке, котоpoe, на наш взгляд, восходит к форме, близкой слвц. Ma(r)muriena, вариант имени 
божества смерти и зимы, чаще выступающего под именами Mara, Mora, Marena, Morena, Marzana и др. (о последнем см. Иванов, Топоров 1994 б: 111).

В слове поляница (поленица), которым постоянно именуется и Настасья, и другие богатыри мужского и женского пола (как по отдельности, так и собирательно) и которое, вероятно, заменило более архаичное образование полянинъ (ср. Белая Поляница и Бельй Полянин в сказках), можно предполагать отражение первоначальной оппозиции по географическому положению (а также по вертикали, как обитателей верхнего и нижнего миров) богатырей младшего поколения по отношению к Святогору. Pol'e : gora - одна из основных оппозиций, характеризующих русскую (славянскую) традиционную картину мира, ср.: “поле противополагается селению, лесу, горам, болоту и пр.” (Даль 1994: 3 646). Эта гипотеза косвенно подтверждается тем обстоятельством, что Святогор - единственный богатырь, который не называется словом поляница (за исключением единственного случая (см. Гильфердинг 1873: 1210), который логично объяснить обобщением тождественных описаний в былинах о Святогоре и Настасье). Аналогичная оппозиция отчетливо выступает (и именно в былине о Святогоре) в следующих былинных строках: “Под Алешей стоял туто Полешанин, Полешанин да Долгополянин” (Гильфердинг 1873: 1199). С учетом хорошо известной в славянских языках соотнесенности значений 'гора' и 'лес' (см. Толстой 1969: 22 и сл.) ее, видимо, следует считать позднейшей трансформацией упомянутой. О наличии в семантической структуре этого слова мифологического компонента свидетельствует русск. диал. (нижегор.) поляница 'по суеверному представлению - злой дух, живущий в полях, на земле' (СРНГ 1965-: 29 57). Эта семантика противопоставлена положительным коннотациям, относящимся к горам, возвышенным местам (о последних см. Иванов, Топоров 1965: 98), ср. в связи с этим первую часть имени Святогор: *svęt- 'святой'.

Таким образом, близкие параллели к образу Настасьи Микуличны, которые являются репрезентациями того же образа (гигантской) девы-воительницы, несомненно подтверждают его связь с загробным миром и происхождение в конечном счете от образа змея у мирового древа - противника бога-громовержца; змея, который также может быть изофункционален самому этому древу.

Доврыня Никитич

Черты и атрибуты громовержца у эпических героев, выступающих в рассматриваемых текстах, проявляются достаточно ясно: болгарская песня “Марко бие първото си либе” рисует образ бури и землетрясения, где палица Марко ассоциируется с молнией или оплодотворяющим дождем (см. Мороз 1996: 79): “Нито гърми, ни се земя тресе, нито вода от високо пада, нито змия у грамада свири, нито камен под бел мрамор дума. Току Марко бие първото си либе” (БФМ 2009-2018); о приближении Добрыни возвещают туча, гром и дождь (“Я ведь видела да чудо чудное, Чудо чудное да диво дивное: Со восточну-ту сторонку как бы туча тучилась, Туча тучилась, как бы гром гремел, Частый мелкий дождик шел; Немного тому времени миновалося, 
Наехал дородный добрый молодец” (Марков 1901: 371), едущий на коне Добрыня поднимает дым от земли до неба (“Подынул Добрынюшко курево, Ай курево Добрынюшко марево, От неба до земли, от земли до неба” (Гильфердинг 1873: 847).

Однако содержание образа Добрыни отнюдь не исчерпывается эпической трансформацией более раннего образа бога-громовержца (такое его понимание выражено, в частности, в Иванов, Топоров 1974: 170-172). Вс. Ф. Миллер собрал богатый сравнительный материал, доказывающий обширность связей между былинами и кавказским, прежде всего нартским эпосом (Миллер 1892), причем Добрыня, в отличие от Святогора и Ильи Муромца, представлен у него лишь двумя-тремя примерами. Между тем целый ряд выразительных (нередко эндемичных) параллелей связывают этого былинного героя с главной фигурой нартского эпоса Сосланом (Созырыко), который характеризуется как солнечный герой (см. Дюмезиль 1976: 69-71) (показательно, что такое же определение дает Добрыне и О. Ф. Миллер (1869: 437 (примечание).

1. Сослан рождается из лежащего в реке камня (Сос-камень) (Нарты 1989: 86). Очевидная реминисценция этого мотива звучит в следующих словах Добрыни: “хотел бы родиться катучим валучим камешком и лежать в синем мори/ Лучше родила б моя матушка Серым горючим камешком, Завертела в тонко полотенышко, Ставала на гору высокую, Розмахала Добрыню - в море бросила" (Гильфердинг 1873: 160, 966) (имеются и другие варианты).

2. Большое влияние на обоих героев имеют их матери, выступающие как могучие волшебницы. Сата́на постоянно помогает Сослану советом и магией (Нарты 1989: 98, 99, 112 и др.). Магические способности матери Добрыни Амельфы Тимофеевны (иногда она выступает и под другими именами) в значительной степени редуцированы, но и она проявляет дар ясновидения (предостерегает своего сына (в былине “Добрыня и змей”) от грозящей ему опасности (поединка со змеем), предсказывает ход будущего боя (Марков 1901: 228), а одной ее угрозы применить магию по отношению к злой колдунье Маринке, чтобы избавить от ее чар Добрыню, оказывается достаточно для достижения желаемого результата (былина “Добрыня и Маринка”) (Гильфердинг 1973: 116-117). Эта важная роль, которую мать играет в его жизни, резко отличает Добрыню от всех других былинных богатырей.

3. Идущий на пир Оразмаг (отчим Сослана), как и Добрыня в аналогичной ситуации (былина “Добрыня и Алеша”), надевает шубу (Нарты 1989: 89), причем нартское сказание устами Сата́ны подробно объясняет причину этого поступка (“Хотят тебя умертвить, и, когда поднесут тебе первую чашу, ты помолись и выпей ее. Вторую поднесут тебе как старшему среди нартов, в ней будет яд, и ты вылей ее в трубку. Надень свою большую шубу, сам садись на шерстяные тюфяки, и тогда вся жидкость будет стекать в них"), тогда как действие Добрыни является немотивированным и его шуба никакой роли в развитии действия не играет, что говорит о вторичном характере этого мотива в былине. Сходство ситуаций здесь не исчерпывается событием пира: Добрыня, отправляющийся на свадьбу собственной жены, имеет, подобно Оразмагу, все основания предполагать, что не будет на ней желанным гостем. 
4. Как и Добрыня, Сослан встречает богатырку, которая кладет его вместе с конем за пазуху, а затем на ладонь (Нарты 1989: 94) (ср. угрозу Настасьи положить Добрыню на ладонь и расплющить как овсяный блин в случае, если он не полюбится ей или откажется взять ее замуж). Однако поведение Сослана в этой ситуации в корне отличается от поведения наследника воинственного громовержца Добрыни: нарт полностью подавлен физическим превосходством своей визави и не помышляет о единоборстве с ней. Это сравнение позволяет отчетливо провести границу между исконным и заимствованным слоями данного эпизода былины. Предположение о кавказских истоках этого эпизода и образа девы-великанши на основе сравнения с другим сказанием (об Алаугане и Эмегене) сделал М. Г. Халанский (1885: 31-33).

5. Сватаясь к Бедухе, Сослан по требованию невесты стреляет в ее воздушную башню (Нарты 1989: 97). Это позволяет интерпретировать нападение Добрыни на Настасью (обычно с помощью палицы или меча, но в одном случае так же, как и в нартском эпосе, стрелами (см. Марков 1901: 312-313) с точки зрения не только сюжета основного мифа, но и ритуала сватовства у предков осетин. В осетинских сказках мы находим неоднократные описания сватовства, в ходе которого жених должен был продемонстрировать свою силу и удаль, причем именно по отношению к невесте: “Я выдам свою дочь только за того, кто сможет разрушить ее башню”; “Елиа решил снова испытать свое счастье, еще раз посвататься. “- Пойду опять покажусь ей еще раз,- сказал он сам себе. - В другом облике она меня не узнает”. Он нагнал темную тучу, стал стрелять, греметь" (Осетинские... 1973: 103, 465). Еще более близкую параллель этому эпизоду нартского сказания, подтверждающую неслучайность связи данного мотива с образом Добрыни, мы находим в былине “Добрыня и Маринка”: стрела героя попадает в окно к опасной чародейке (убивая ее любовника Туга-змеевича), которая тут же просит Добрыню взять ее замуж (Гильфердинг 1873: 116 и др.).

6. Сослана и Добрыню сближает также мотив ложной гибели. Сослан неоднократно притворяется мертвым на поле боя, вследствие чего родным сообщают о его смерти (Нарты 1989: 117, 120); это напоминает ложное известие о гибели Добрыни, которое приносит его матери Алеша Попович (“Добрыня и Алеша”).

7. Оба богатыря не чужды веселью, забаве, что не совсем обычно для эпических героев этого типа: Добрыня на пиру своей игрой на гуслях доставляет живую радость всем присутствующим; Сослан охарактеризован следующим образом: “Он был единственным славным мужем между нами, единственным весельчаком, приводившим нас в живость, заставлявшим забывать нас тяжелые часы жизни" (Нарты 1989: 138).

Таким образом, есть все основания говорить о сложности образа Добрыни, в котором исконные мифологические черты бога-громовержца соединены с заимствованиями из восточноиранского эпоса. 


\section{ЗАКЛЮЧЕНИЕ}

Анализ сюжета и образной структуры былины “Добрыня и Настасья” в сравнении с данными славянского, балтийского и иранского фольклора позволил выявить и обосновать ее мифологическую основу. Характерно, что в каждой из рассмотренных версий основного мифа он предстает в неполном, деградированном виде; лишь их совокупность позволяет восстановить все его ключевые части и мотивы. Это обстоятельство лишний раз доказывает методологическую важность учета при анализе фольклорных текстов всех возможных вариантов, в т. ч. и в родственных языках.

Другой важный вывод заключается в том, что эпические сюжеты и образы часто формируются во взаимодействии разных культурных традиций. В силу этого они не могут быть возведены к одному источнику или прототипу, но содержат несколько генетических и/или хронологических слоев.

Перспективы дальнейшего исследования связаны с более широким и детальным сравнительным анализом былинных текстов (особенно в их редких, малоизвестных вариантах) и произведений устного народного творчества индоевропейских народов, среди которых южнославянский, балтийский и восточноиранский материал будет, как показывают результаты проведенного исследования, играть наиболее важную роль.

\section{ЛИТЕРАТУРА}

Андреев, Н. П., 1929: Указатель сказочных сюжетов по системе Аарне. Ленинград: Издание Государственного Русского географического общества. [Andreev, N. P., 1929: Ukazatel skazochnykh syuzhetov po sisteme Aarne. Leningrad: Izdanie Gosudarstvennogo Russkogo geograficheskogo obshchestva.]

Афанасьев, Александр Н., [1865-1869]: Поэтические воззрения славян на природу. Internet: biblio.imli.ru (10.04.2019). [Afanasyev, Aleksandr N., [1865-1869]: Poéticheskie vozzreniya slavyan na prirodu. Internet: biblio.imli.ru (10.04.2019).]

БФМ 2009-2018, Тодор Моллов (съст.), Български фолклорни мотиви, т. III: Юнашки песни. Варна: LiterNet. Internet: https://liternet.bg/ (10.04.2019). [BFM 2009-2018, Todor Mollov (sast.), Balgarski folklorni motivi, t. III: Yunashki pesni. Varna: LiterNet. Internet: https:// liternet.bg/ (10.04.2019).]

БНТ 1961, Българско народно творчество в дванадесет тома, т. IV: Митически песни. София: Български писател. [BNT 1961, Balgarsko narodno tvorchestvo v dvanadeset toma, t. IV: Miticheski pesni. Sofiya: Balgarski pisatel.]

Былины Печоры и Зимнего берега (новые записи) 1961. Москва; Ленинград: Издательство Академии наук СССР. [Byliny Pechory i Zimnego berega (novye zapisi), 1961. Moskva; Leningrad: Izdatel'stvo Akademii nauk SSSR.]

Былины Пудожского края 1941. Петрозаводск: Карельское государственное издательство. [Byliny Pudozhskogo kraya. Petrozavodsk: Karel'skoe gosudarstvennoe izdatel'stvo.]

Великорусские сказки в записях И. А. Худякова 1964. Москва; Ленинград: Наука. [Velikorusskie skazki v zapisyakh I. A. Khudyakova 1964. Moskva; Leningrad: Nauka.] 
Гильфердинг 1873, Онежские былины, записанные Александром Федоровичем Гильфердингом летом 1871 года. Санкт-Петербург. [Gil'ferding 1873, Onezhskie byliny, zapisannye Aleksandrom Fyodorovichem Gilferdingom letom 1871 goda. Sankt-Peterburg.]

Григорьев 1904, Архангельские былины и исторические песни, собранные А. Д. Григорьевым в 1899-1901 гz., т. І. Москва: Издание Императорской Академии наук. [Grigor'ev 1904, Arkhangel'skie byliny i istoricheskie pesni, sobrannye A. D. Grigor'evym v 1899-1901 gg., t. I. Moskva: Izdanie Imperatorskoĭ Akademii nauk.]

Даль, Владимир И., 1994: Толковый словарь живого великорусского языка. Москва: Издательская группа “Прогресc”. [Dal', Vladimir I., 1994: Tolkovyı̌ slovar' zhivogo velikorusskogo yazyka. Moskva: Izdatel'skaya gruppa "Progress".]

Добрыня Никитич и Алеша Попович 1974. Москва: Наука. [Dobrynya Nikitich i Alyosha Popovich 1974. Moskva: Nauka.]

Дюмезиль, Жорж, 1976: Осетинский эпос и мифология. Москва: Главная редакция восточной литературы издательства “Наука". [Dyumezil', Zhorzh, 1976: Osetinskiu épos i mifilogiya. Moskva: Glavnaya redaktsiya vostochnoî literatury izdatel'stva "Nauka".]

Иванов, Вячеслав В.; Топоров, Владимир Н., 1965: Славянские языковые моделируюшие семиотические системы (древний период). Москва: Наука. [Ivanov, Vyacheslav V.; Toporov, Vladimir N. 1965. Slavyanskie yazykovye modeliruyushchie semioticheskie sistemy (drevnil period). Moskva: Nauka.]

Иванов, Вячеслав В.; Топоров, Владимир Н., 1974: Исследования в области славянских древностей. Москва: Наука. [Ivanov, Vyacheslav V.; Toporov, Vladimir N., 1974: Issledovaniya v oblasti slavyanskikh drevnosteŭ. Moskva: Nauka.]

Иванов, Вячеслав В.; Топоров, Владимир Н., 1990: Горыня, Дубыня и Усыня. Мелетинский, Е. М. (ред.), Мифологический словарь. Москва: Советская энциклопедия, 159-160. [Ivanov, Vyacheslav V.; Toporov, Vladimir N., 1990: Gorynya, Dubynya i Usynya. Meletinskiĭ, E. M. (red.), Mifologicheskiŭ slovar'. Moskva: Sovetskaya èntsiklopediya, 159-160.]

Иванов, Вячеслав В.; Топоров, Владимир Н., 1994 а: Вырий. Токарев, С. А. (ред.), Мифы народов мира. Энииклопедия, т. І. Москва: Российская энциклопедия; Минск: Дилер; Смоленск: Русич, 244. [Ivanov, Vyacheslav V.; Toporov, Vladimir N. 1994 a: Vyrī̌. Tokarev, S. A. (red.), Mify narodov mira. Entsiklopediya, t. I. Moskva: Rossiǔskaya èntsiklopediya; Minsk: Diler; Smolensk: Rusich, 244.]

Иванов, Вячеслав В.; Топоров, Владимир Н., 1994 б: Марена. Токарев, С. А. (ред.), Мифы народов мира. Энциклопедия, т. II. Москва: Российская энциклопедия; Минск: Дилер; Смоленск: Русич, 111. [Ivanov, Vyacheslav V.; Toporov, Vladimir N., 1994 b: Marena. Tokarev, S. A. (red.), Mify narodov mira. Entsiklopediya, t. II. Moskva: Rossiǐskaya èntsiklopediya; Minsk: Diler; Smolensk: Rusich, 111.]

Иванов, Вячеслав В.; Топоров, Владимир Н., 1994 в: Птицы. Токарев, С. А. (ред.), Мифы народов мира. Энциклопедия, т. II. Москва: Российская энциклопедия; Минск: Дилер; Смоленск: Русич, 346-349. [Ivanov, Vyacheslav V.; Toporov, Vladimir N. 1994 v: Ptitsy. Tokarev, S. A. (red.), Mify narodov mira. Éntsiklopediya, Vol. II. Moskva: Rossiřskaya èntsiklopediya; Minsk: Diler; Smolensk: Rusich, 346-349.]

Илья Муромеи 1958. Москва; Ленинград: Издательство Академии наук СССР. [Il'ya Muromets 1958. Moskva; Leningrad: Izdatel'stvo Akademii nauk SSSR.]

Караџић, Вук С., 1870: Међедовић. Караџић, В. С., Српске народне приповијетке. Беч: у наклади Ане, удовице В. С. Караџића, 1-7. [Karadžić, Vuk S., 1870: Međedović. Karadžić, V. S., Srpske narodne pripovijetke. Beč: u nakladi Ane, udovice V. S. Karadžića, 1-7.] 
Коргуев 1939, Сказки Карельского Беломорья, т. I, кн. 2: Сказки М. М. Коргуева. Петрозаводск: Карельское государственное издательство. [Korguev 1939, Skazki Karel'skogo Belomorya, t. I, kn. 2: Skazki M. M. Korgueva. Petrozavodsk: Karel'skoe gosudarstvennoe izdatel'stvo.]

Крюкова 1939, Былины М. С. Крюковой. Москва: Государственный литературный музей (Летописи Государственного литературного музея. Книга шестая). [Kryukova 1939, Byliny M. S. Kryukovol̆. Moscow: Gosudarstvennyı̆ literaturnyı̆ muzeĭ (Letopisi Gosudarstvennogo literaturnogo muzeya. Kniga shestaya).]

Кулишић, Ш.; Петровић, П. Ж.; Пантелић, Н., 1970: Српски митолошки речник. Београд: Нолит. [Kulišić, Š.; Petrović, P. Ž.; Pantelić, N., 1970: Srpski mitološki rečnik. Beograd: Nolit.]

Марков 1901, Беломорские былины, записанные А. В. Марковым. Москва: Т-во скоропечатни А. А. Левенсон (Этнографический отдел Императорского общества любителей естествознания, антропологии и этнографии). [Markov 1901, Belomorskie byliny, zapisannye A. V. Markovym. Moskva: T-vo skoropecatni A. A. Levenson (Ëtnograficheskiı̌ otdel Imperatorskogo obshchestva lyubiteleĭ estestvoznaniya, antropologii i ètnografii).]

Миллер, Всеволод, 1892: Экскурсы в область русского народного эпоса I-VIII. Москва: Типография Т-ва И. Н. Кушнерева и К․ [Miller, Vsevolod, 1892: Ekskursy v oblast russkogo narodnogo éposa I-VIII. Moskva: Tipografiya T-va I. N. Kushnereva i ${ }^{\circ}$.]

Миллер, Орест Ф., 1869: Илья Муромеи и богатырство Киевское: сравнительно-критические наблюдения над слоевым составом народного русского эпоса. Санкт-Петербург: Типография Н. И. Михайлова. [Miller, Orest F., 1869: Ilya Muromets i bogatyrstvo Kievskoe: sravnitelno-kriticheskie nablyudeniya nad sloevym sostavom narodnogo russkogo éposa. Sankt-Peterburg: Tipografiya N. I. Mikhaĭlova.]

Мороз, И., 1996: Сюжет языческого праздника в староболгарской песне из Ходошского сборника XIV в. Этнографическое обозрение 2, 74-80. [Moroz, I., 1996: Syuzhet yazycheskogo prazdnika v starobolgarskoĭ pesne iz Khodoshskogo sbornika XIV v. Ėtnograficheskoe obozrenie 2, 74-80.]

Народные русские сказки А. Н. Афанасьева в трех томах 1984-1985. Москва: Наука (Литературные памятники). [Narodnye russkie skazki A. N. Afanasyeva v trekh tomakh 1984-1985. Moskva: Nauka (Literaturnye pamyatniki).]

Нарты 1989, Hарты. Осетинский героический эпос, кн. 2. Москва: Наука. Главная редакция восточной литературы. [Narty 1989, Narty. Osetinskil geroicheskil̆ épos, kn. 2. Moskva: Nauka. Glavnaya redaktsiya vostochnoĭ literatury.]

Новичкова, Т. А., 1987: Эпическое сватовство и свадебный обряд. Еремина, В. И. (ред.), Русский фольклор XXIV: Этнографические истоки фольклорных явлений. Ленинград: Наука. Ленинградское отделение, 3-20. [Novichkova, T. A., 1987: Épicheskoe svatovstvo i svadebnyı̌ obryad. Eremina, V. I. (red.), Russkiǔ fol'klor XXIV: Etnograficheskie istoki folklornykh yavlenil. Leningrad: Nauka. Leningradskoe otdelenie, 3-20.]

Осетинские народные сказки 1973. Москва: Наука. Главная редакция восточной литературы (Сказки и мифы народов Востока). [Osetinskie narodnye skazki 1973. Moskva: Nauka. Glavnaya redaktsiya vostochnoй literatury (Skazki i mify narodov Vostoka).]

Песни южных славян 1976. Москва: Художественная литература (Библиотека мировой литературы). [Pesni yuzhnykh slavyan 1976. Moskva: Khudozhestvennaya literatura (Biblioteka mirovoĭ literatury).].

Петровић, Сретен, 1999: Српска митологија. Систем српске митологије, т. І. Ниш: Просвета. [Petrović, Sreten, 1999: Srpska mitologija. Sistem srpske mitologije, t. I. Niš: Prosveta.] 
Путилов, Борис Н., 1971: Русский и южнославянский героический эпос: сравнительнотипологическое исследование. Москва: Наука. [Putilov, Boris N., 1971: Russkiŭ i yuzhnoslavyanskiu geroicheskil épos: sravnitel'no-tipologicheskoe issledovanie. Moskva: Nauka.]

Путилов, Борис Н., 1999: Экскурсы в теорию и историю славянского эпоса. Санкт-Петербург: Петербургское востоковедение. [Putilov, Boris N., 1999: Ékskursy v teoriyu i istoriyu slavyanskogo éposa. Sankt-Peterburg: Peterburgskoe vostokovedenie.]

Сборник антропологических и этнографических статей о России и странах ей прилежащих 1873. Москва: Типография В. Готье (Труды Императорского общества любителей естествознания, антропологии и этнографии, т. ХІІ: Труды Этнографического отдела, кн. II). [Sbornik antropologicheskikh i ètnograficheskikh statel o Rossii i stranakh ě prilezhashchikh 1873. Moskva: Tipografiya V. Got'e (Trudy Imperatorskogo obshchestva lyubitelei estestvoznaniya, antropologii i ètnografii, t. XII: Trudy Ėtnograficheskogo otdela, kn. II).]

Сказки 1988, Библиотека русского фольклора, т. 2: Сказки, кн. 1. Москва: Советская Россия. [Skazki 1988, Biblioteka russkogo fol'klora, t. 2: Skazki, kn. 1. Moskva: Sovetskaya Rossiya.]

Сказки 1989, Библиотека русского фольклора, т. 2: Сказки, кн. 2. Москва: Советская Россия. [Skazki 1989, Biblioteka russkogo fol'klora, t. 2: Skazki, kn. 2. Moskva: Sovetskaya Rossiya.]

Сказки Белозерского края 1981 / Записали Б. М. и Ю. М. Соколовы. Архангельск: СевероЗападное книжное издательство. [Skazki Belozerskogo kraya 1981 / Zapisali B. M. і Yu. M. Sokolovy. Arkhangel'sk: Severo-Zapadnoe knizhnoe izdatel'stvo.]

Сказки народов Югославии 1962. Москва: Государственное издательство художественной литературы. [Skazki narodov Yugoslavii 1962. Moskva: Gosudarstvennoe izdatel'stvo khudozhestvennoĭ literatury.]

СРНГ 1965-, Филин, Федот П. (ред.), Словарь русских народных говоров. Ленинград: Наука. Ленинградское отделение. [SRNG 1965-, Filin, Fedot P. (red.), Slovar'russkih narodnyh govorov. Leningrad: Nauka. Leningradskoe otdelenie.]

Сравнительный указатель сюжетов. Восточнославянская сказка 1979. Ленинград: Наука. Ленинградское отделение. [Sravnitel'nyı ukazatel' syuzhetov. Vostochnoslavyanskaya skazka 1979. Leningrad: Nauka. Leningradskoe otdelenie.]

Толстой, Никита И., 1969: Славянская географическая терминология. Семасиологические этюды. Москва: Наука. [Tolstō̆, Nikita I., 1969: Slavyanskaya geograficheskaya terminologiya. Semasiologicheskie ètyudy. Moskva: Nauka.]

Толстые, Никита И.; Светлана М., 1978: Заметки по славянскому язычеству. 2. Вызывание дождя в Полесье. Шептунов, И. М. (ред.), Славянский и балканский фольклор. Москва: Наука, 95-130. [Tolstye, Nikita I.; Svetlana M., 1978: Zametki po slavyanskomu yazychestvu. 2. Vyzyvanie dozhdya v Poles'e. Sheptunov, I. M. (red.), Slavyanskiü i balkanskiu fol'klor. Moskva: Nauka, 95-130.]

Топоров, Владимир Н., 1986: К реконструкции одного цикла архаичных мифопоэтических представлений в свете "Latvju dainas" (к 150-летию со дня рождения Кр. Барона). Иванов, Вяч. Вс. (ред.), Балто-славянские исследования 1984. Москва: Наука, 29-58. [Toporov, Vladimir N., 1986: K rekonstruktsii odnogo tsikla arkhaichnykh mifopoèticheskikh predstavleniǐ v svete "Latvju dainas" (k 150-letiyu so dnya rozhdeniya Kr. Barona). Ivanov, Vyach. Vs. (red.), Balto-slavyanskie issledovaniya 1984. Moskva: Nauka, 29-58.]

Топоров, Владимир Н., 1994: Древо мировое. Токарев, С. А. (ред.), Мифы народов мира. Энциклопедия, т. І. Москва; Минск; Смоленск: Российская энциклопедия, 398-406. [Toporov, Vladimir N., 1994: Drevo mirovoe. Tokarev, S. A. (red.), Mify narodov mira. Entsiklopediya, t. I. Moskva; Minsk; Smolensk: Rossiřskaya èntsiklopediya, 398-406.] 
Топорова, Татьяна В., 2011: Об образе дуба в русских былинах и реконструкции формулы сырой дуб - мать сыра земля. Балты и славяне: пересечения духовных культур. Тезисы докладов международной научной конференции, посвященной академику $B$. $H$. Tопоровy. Vilnius: Lietuvos Respublikos Seimo Kanceliarija, 59-60. [Toporova, Tatyana V., 2011: Ob obraze duba v russkikh bylinakh i rekonstruktsii formuly syrŏ dub - mat' syra zemlya. Balty i slavyane: peresecheniya dukhovnykh kultur. Tezisy dokladov mezhdunarodnŏ nauchnoĭ konferentsii, posvyashchennoĭ akademiku V. N. Toporovu. Vilnius: Lietuvos Respublikos Seimo Kanceliarija, 59-60.]

Фасмер, Макс, 1996: Этимологический словарь русского языка. Санкт-Петербург: Азбука. [Fasmer, Maks, 1996: Ėtimologicheskil slovar'russkogo yazyka. Sankt-Peterburg: Azbuka.]

Фрэзер, Джеймс Дж., 1986: Золотая ветвь. Москва: Политиздат. [Frėzer, Dzheyms Dzh., 1986: Zolotaya vetv’. Moskva: Politizdat.]

Халанский, Михаил, 1885: Великорусские былины киевского цикла. Варшава: В типографии Михаила Земкевича. [Khalanski1̌, Mikhail, 1885: Velikorusskie byliny kievskogo tsikla. Varshava: V tipografii Mikhaila Zemkevicha.]

Халанский, Михаил, 1893: Южнославянские сказания о Кралевиче Марке в связи с произведениями русского былевого эпоса. Сравнительные наблюдения в области героического эпоса южных славян и русского народа. (Дополнения и поправки к I-III глав.). Русский филологический вестник 2, 308-325. [Khalanski1̌, Mikhail, 1893: Yuzhnoslavyanskie skazaniya o Kraleviche Marke v svyazi s proizvedeniyami russkogo bylevogo ėposa. Sravnitel'nye nablyudeniya v oblasti geroicheskogo ėposa yuzhnykh slavyan i russkogo naroda. (Dopolneniya i popravki k I-III glav.). Russkiu filologicheski vestnik 2, 308-325.]

Aarne, Antti, 1910: Verzeichnis der Märchentypen. Helsinki: Suomalainen Tiedeakatemian toimituksia.

Dainu skapis, Krišjāna Barona Dainu skapis. Internet: http://www.dainuskapis.lv/ (08.04.2019).

Holmberg, Uno, 1927: Finno-Ugric [Mythology]. MacCulloch, C. J. A. (ed.), The Mythology of all Races, vol. IV: Finno-Ugric, Siberian. Boston: Archeological Institute of America. Marshall Jones Company, 3-298.

Šmits, Pēteris, 1926: Latviešu mītologija. Rīga: Valters un Rapa.

Thompson, Stith, 1961: The Types of the Folktales. A Classification and Bibliography. Helsinki: Suomalainen Tiedeakatemia / Academia Scientiarum Fennica (FF Communications, No. 3).

Wollner, Wilhelm, 1879: Untersuchungen über die Volksepik der Grossrussen. Leipzig: Verlag von Wilhelm Engelmann. 


\section{ON THE MYTHOLOGICAL MOTIFS IN THE BYLINA “DOBRYNYA AND NASTAS'YA" \\ MAXIM A. YUYUKIN \\ $\infty$}

This article deals with mythological motifs reflected in the bylina "Dobrynya and Nastas'ya" discussed in comparison with the Baltic, South Slavic, and Ossetic epic texts. This work of Russian oral literature has not been mentioned thus far among the bylinas that have preserved traces of the East Slavic mythology. The close connection of the motifs of (oak-)tree splitting and of weddings (i.e., combat against a female rival if we take into consideration the folk metaphor "wedding - battle"), which we find in it, allows comparing this bylina with the Lettish and Bulgarian epic songs representing variants of the principal Indo-European myth. The author analyses the genetic relations of many details of these texts in order to explain their origin, mutual connections, and transformations.

Considerable attention is also given to the images of the main personages. The image of the warrior maiden Nastas'ya Mikulichna is included in the range of associations leading to the figure of a creature who belongs to the infernal world, and, finally, to the image of a snake near the world tree - a rival of the thunderstorm god. Numerous parallels connecting the image of Dobrynya with the main figure of the Ossetic Nart epic Soslan/Sozyryko (some of which are secondary in the bylinas) indicate its compound character, which combines the original features of the thunderstorm god with borrowings from the East Iranian epic.

Maxim Anatol'evich Yuyukin, Ph.D., Moiseeva, 47/55, RU-394055, Voronezh, Russia; yuyukin@bk.ru 